\title{
Quality characteristics of milk bread added blueberry starter
}

\author{
Kum-Hee Hwang ${ }^{1}$, Hee-Nam Jung ${ }^{2}$, Ok-Ja Choi ${ }^{2 *}$ \\ ${ }^{1}$ Department of Hotel Culinary art and Nutrition, Dongkang College, Gwangju 61200, Korea \\ ${ }^{2}$ Department of Food and Cooking Science, Sunchon National University, Sunchon 57922, Korea
}

\section{블루베리 발효액종의 첨가량에 따른 우유식빵의 품질특성}

\author{
황금희 ${ }^{1} \cdot$ 정희남 ${ }^{2} \cdot$ 최옥자 ${ }^{2 *}$ \\ ${ }^{1}$ 동강대학교 호텔조리영양학부, ${ }^{2}$ 순천대학교 조리과학과
}

\begin{abstract}
This study investigated the quality characteristics of milk bread with bluebeny starter for the development of various bakery products. Blueberry starter was added to milk content at levels of 10, 20, 30, 40, and $50 \%$ to produce milk bread. As fermentation time increased, the $\mathrm{pH}$ of the blueberry starter decreased, whereas the titratable acidity and sugar level increased. The dough volume during fermentation was the highest for the group containing $40 \%$ added blueberry starter and the lowest for group containing $10 \%$ added blueberry starter. In the group containing $30 \%$ and $\mathbf{4 0 \%}$ added bluebery starter, The volume, specific volume and baking loss of milk bread were the highest, while moisture content was the lowest. With regard to the crumb color value of the milk bread with blueberry starter, the $L$ value decreased and the $a$ and $b$ values increased as the amount of bluebeny starter increased. Hardness, gumminess and chewiness were the lowest in the group with $40 \%$ added bluebeny starter. The results of this study indicate that the optimal amount of bluebeny starter for the preparation of milk bread is $30-40 \%$.
\end{abstract}

Key words : blueberry, starter, bread, quality characteristics

\section{서 론}

최근 맞벌이 부부 및 1 인 가구 증가로 식생활의 간편화를 추구하는 인구가 많아짐에 따라 밥을 주식으로 하는 전통적 인 식생활에서 벗어나 샌드위치, 토스트, 베이글 등 간편하 게 즐길 수 있는 빵류 제품의 소비가 증가하고 있다(1). 또한 국민 소득의 향상과 노인 인구 증가로 인해 건강에 대한 관심이 높아지면서 식품 선택에 있어서 건강지향적인 식품을 선호하고, 흡연, 음주, 운동부족 등의 생활패턴으로 인한 암, 동맥경화, 당뇨, 뇌혈관질환과 같은 질병이 사회적 문제로 대두되어 식품의 기능성 성분에 대한 관심이 높아지 고 있다(2,3). 이와 같이 건강한 식품을 선택하려는 소비자

*Corresponding author. E-mail : coj@sunchon,ac,kr

Phone : 82-61-750-3692, Fax : 82-61-750-3692

Received 28 February 2018; Revised 24 May 2018; Accepted 11 June 2018.

Copyright (c) The Korean Society of Food Preservation. All rights reserved.
가 증가하면서 키토산, 쑥, 청국장, 클로렐라, 스피루리나 등 다양한 생리활성이 있는 기능성 소재를 제빵에 활용한 연구들이 보고되었다(4-8). 또한 베이커리 산업에서는 빵의 맛과 풍미 향상, 발효 안정성 및 대량 생산을 위하여 많은 식품 첨가물이 사용되고 있어 식품첨가물의 사용을 줄이고 천연재료를 이용하여 빵의 품질을 개선하려는 연구들이 많이 시도되었다(9-12).

빵의 발효에 이용되는 효모는 채소, 과일, 곡물을 비롯하 여 대부분의 식품에 존재하는데, 발효액종은 과일이나 곡 물에 존재하는 효모를 자연발효 시킨 것을 말하며, 천연재 료를 멸균된 병에 물과 함께 담아 적정한 온도로 유지시키 면 효모가 증식되어 천연발효종이 된다(13). 천연발효종은 과일과 곡물이 지니고 있는 맛과 향이 천연효모의 발효를 통해 더욱 깊고 풍부한 향미를 만들어 내어 빵의 풍미를 향상시키게 된다(14). 과일을 이용한 발효종은 당도가 높은 과일일수록 생과일보다는 당분이 응축된 건조과일이 발효 력이 뛰어난 것으로 알려져 있다(15). 그러나 발효액종에 관한 국내 연구로는 홍국을 이용한 발효액종(16)에 관한 
연구와 sourdough를 제조하기 위해 무화과(17), 홍국(18), 머루(11) 등을 이용한 연구들이 보고되었으나 발효액종에 관한 연구는 미흡한 실정이다.

블루베리는 비타민 및 각종 무기질이 풍부하고, 항암, 항염증, 항산화작용이 있는 페놀화합물과 안토시아닌과 같은 파이토케미칼이 다량 함유되어 있는 식품 원료이다 (19-21). 이러한 효능으로 블루베리는 2002년 미국 시사 주간지인 타임에서 10 대 건강식품으로 소개되었고, 최근 블랙푸드의 기능성에 대한 관심이 높아지면서 블루베리에 영양성과 생리활성에 대한 연구가 다양하게 이루어지고 있다(22-24). 블루베리를 식품에 활용한 연구로는 막걸리, 양갱, 잼 등이 있으나 $(20,21,25)$, 제빵에서의 블루베리 활용 에 관한 연구는 미흡한 실정으로, 블루베리를 이용하여 발 효액종을 제조하고, 제조된 발효액종을 빵의 발효에 이용 한다면 블루베리의 기능성과 더불어 발효특성 및 물성 등의 품질 향상도 기대해 볼 수 있을 것으로 생각된다.

따라서 본 연구는 블루베리를 이용하여 발효액종을 제조 한 다음, 발효액종 첨가량에 따른 우유식빵의 발효력, 부피, 비용적, 색도, 물성 등을 측정하여 발효액종의 최적첨가량 을 결정하였고, 다양한 베이커리 제품 개발을 위한 기초자 료로 활용하고자 하였다.

\section{재료 및 방법}

재 료

본 연구에 사용된 재료는 건블루베리(Kirkland signature, Costco wholesale industries packaging, San Diego, CA, USA), 탈지분유(Skim milk powder, Maeil Dairies Co., Ltd., Seoul, Korea), 강력분(Elephant strong wheat flour, Daehan Flour Co., Seoul, Korea), 버터(Lotte milk butter white, Lotte Samkang Co., Seoul, Korea), 설탕(White sugar, CJ Cheiljedang, Seoul, Korea), 소금(Fine salt, CJ Cheiljedang), 효모(Saf Instant Yeast Red, Societe Industrielle Lesaffre, Marcq en Baroeul, France)이며, 시중에서 각각 구입하여 사용하였다.

\section{블루베리 발효액종의 제조}

블루베리 발효액종의 제조는 예비실험을 통하여 재료의 양과 발효온도 및 발효시간의 최적조건을 결정하였다. 즉 $10 \%$ 탈지분유액 $400 \mathrm{~g}$ 에 블루베리 $100 \mathrm{~g}$ 을 넣고 잘 혼합한 다음, $27^{\circ} \mathrm{C}$ incubator(HB-101M, Hanbaek, Bucheon, Korea) 에서 총 48 시간 발효하였으며, 12 시간 간격으로 발효액종 의 변화를 측정하였다.

발효액종의 $\mathrm{pH}$, 적정산도 및 가용성 고형분 변화 측정 발효시간에 따른 블루베리 발효액종의 $\mathrm{pH}$ 및 적정산도
변화 측정은 $27^{\circ} \mathrm{C}$ 에서 총 48 시간 발효하면서 12 시간 간격 으로 측정하였으며, $\mathrm{pH}$ 측정은 블루베리 발효액종 $50 \mathrm{~g}$ 을 비이커에 담고 $\mathrm{pH}$ meter(Accumet 925, Fisher scientific, Pittsburgh, $\mathrm{PA}, \mathrm{USA})$ 로 측정하였다. 적정산도 측정은 시료 $3 \mathrm{~g}$ 과 증류수 $30 \mathrm{~mL}$ 를 섞어 30 분간 원심분리 한 상등액을 삼각플라스크에 취하여 사용하였고, phenolphthalein 지시 약 2-3방울을 넣고 $0.1 \mathrm{~N} \mathrm{NaOH}$ 로 중화 적정하여 소요된 $\mathrm{NaOH}$ 의 양을 계산하여 lactic $\operatorname{acid}(\%)$ 로 표시하였다. 가용 성 고형분 함량은 당도계(PAL-1, ATAGO Co., Tokyo, Japan)를 이용하여 측정하였고, 그 값을 ${ }^{\circ} \mathrm{Brix}$ 로 나타내었다.

\section{우유식빵의 제조}

블루베리 발효액종의 첨가량에 따른 우유식빵의 배합은 Table 1과 같다. 블루베리 발효액종의 첨가량에 따른 우유 식빵의 제조를 위하여 예비실험 결과를 바탕으로 블루베리 발효액종의 첨가량과 발효시간을 결정하였다. 또한 블루베 리 발효액종을 첨가하지 않고 이스트만으로 발효한 무첨가 구는 발효시간에 차이가 있어 발효액종 첨가구와 같은 조건 으로 발효할 수 없어 실험에서 제외하였고, 본 연구는 블루 베리 발효액종의 최적첨가량에 목적을 두고 실험하였다. 블루베리 발효액종의 첨가비율은 강력분의 $70 \%$ 를 우유의 기준량으로 하였을 때 우유량의 $10,20,30,40$ 및 $50 \%$ 를 각각 블루베리 발효액종으로 대체하여 우유식빵을 제조하 였다. 각 배합의 설탕 양은 모든 시료의 가용성 고형분을 동일하게 할 목적으로 완성된 블루베리 발효액종의 최종 가용성 고형분이 $21.73{ }^{\circ} \mathrm{Brix}$ 임을 감안하여 강력분 함량을 기준으로 $8{ }^{\circ} \mathrm{Brix}$ 가 되도록 블루베리 발효액종의 첨가량에 따라 설탕 양을 조절하였다. 우유식빵의 반죽은 각 시료의 재료를 반죽기(5KPM5E, Whirlpool Inc., Benton Harbor, MI, $\mathrm{USA}$ )에서 저속으로 2 분, 중속으로 8 분간 반죽하였고, 이때 반죽온도는 $27^{\circ} \mathrm{C}$ 로 하였다. 반죽 후 1 차 발효는 온도 $27^{\circ} \mathrm{C}$, 습도 $75 \%$ 에서 90 분간 하였고, 1 차 발효 후 반죽을 $180 \mathrm{~g}$ 씩 분할하여 둥글리기 한 후 15 분간 실온에서 중간발효를 하 였다. 중간발효가 끝난 반죽은 성형하여 식빵 팬(윗면 21.5 $\mathrm{cm} \times 9.5 \mathrm{~cm}$, 높이 $9 \mathrm{~cm}$ )에 3 개 씩 넣고 온도 $35^{\circ} \mathrm{C}$, 습도

Table 1. Formula of milk bread dough with blueberry starter

\begin{tabular}{cccccc}
\hline \multirow{2}{*}{ Ingredient } & \multicolumn{5}{c}{ Blueberry starter (\%) } \\
\cline { 2 - 6 } & 10 & 20 & 30 & 40 & 50 \\
\hline Wheat flour & 100 & 100 & 100 & 100 & 100 \\
Butter & 4 & 4 & 4 & 4 & 4 \\
Sugar & 6.46 & 4.92 & 3.38 & 1.84 & 0.3 \\
Salt & 2 & 2 & 2 & 2 & 2 \\
Yeast & 1.25 & 1.25 & 1.25 & 1.25 & 1.25 \\
Milk & 63 & 56 & 49 & 42 & 35 \\
Blueberry starter & 7 & 14 & 21 & 28 & 35 \\
\hline
\end{tabular}


$85 \%$ 에서 90 분간 2 차 발효하였다. 2차 발효한 반죽을 윗불 $190^{\circ} \mathrm{C}$, 아랫불 $200^{\circ} \mathrm{C}$ 의 전기오븐(CPC-102, Dae Yung machinary Co., Seoul, Korea)에서 25분간 구웠다. 구워진 식빵은 실온에서 1 시간 방냉한 후 식빵의 품질특성을 분석 하였다.

\section{우유식빵 반죽의 발효과정 중 부피 변화 측정}

블루베리 발효액종을 첨가한 우유식빵 반죽의 발효시간 에 따른 부피 변화 측정은 1 차 발효와 2 차 발효로 나누어 각각 90 분간 발효하면서 반죽의 변화를 측정하였다. 1 차 발효의 부피 변화는 믹싱된 반죽 $50 \mathrm{~g}$ 을 $200 \mathrm{~mL}$ 메스실린더 에 넣고, 온도 $27^{\circ} \mathrm{C}$, 습도 $75 \%$ 에서 90 분간 발효를 하면서 30 분 간격으로 반죽의 높이를 측정하였다. 2 차 발효의 부피 변화는 1 차 발효된 반죽을 가스빼기 하여 $50 \mathrm{~g}$ 을 취하여 $200 \mathrm{~mL}$ 메스실린더에 넣고 온도 $35^{\circ} \mathrm{C}$, 습도 $85 \%$ 에서 90 분 간 발효하면서 30 분 간격으로 반죽의 높이를 측정하였으 며, 반죽의 부피는 $\mathrm{mL}$ 로 나타내었다.

\section{우유식빵의 부피, 비용적 및 굽기손실률 측정}

우유식빵의 무게 측정은 $180 \mathrm{~g}$ 의 반죽 3 개를 식빵 팬에 구운 후 실온에서 1 시간 방냉하여 무게를 측정하였다. 우유 식빵의 부피 측정은 종자치환법(26)을 이용하여 측정하였 다. 즉 우유식빵을 측정용기에 넣고 참깨를 가득 부어 스파 튤라로 측정용기 윗면을 평평하게 깍은 후 참깨의 부피를 측정하여 식빵의 부피를 구하였다. 비용적은 식빵의 중량 에 대한 식빵 부피의 비 $(\mathrm{mL} / \mathrm{g})$ 로 표시하였다. 굽기손실률은 반죽무게와 식빵 무게의 차이로부터 굽는 동안 손실된 무게 의 비율을 다음의 식에 의해 계산하였다.

$$
\text { 굽기손실률 }(\%)=\frac{\text { 반죽무게-식빵의 무게 }}{\text { 반죽무게 }} \times 100
$$

\section{우유식빵의 수분함량 측정}

블루베리 발효액종의 첨가량에 따른 우유식빵의 수분함 량 측정은 $105^{\circ} \mathrm{C}$ 상압가열법(27)을 이용하여 측정하였다.

\section{우유식빵의 단면구조 관찰}

블루베리 발효액종의 첨가량에 따른 우유식빵의 단면구 조 관찰은 식빵을 실온에서 1시간 방냉한 후 단면을 잘라 비디오현미경(SV-32, Sometech Co., Seoul, Korea)으로 40 배율 렌즈를 이용하여 기공의 크기와 형태를 관찰하였다.

\section{우유식빵의 색도 측정}

블루베리 발효액종의 첨가량에 따른 우유식빵의 색도 측정은 색차계(JC 801S, Color techno system, Tokyo, Japan) 를 사용하여 crumb 부분과 crust 부분의 $\mathrm{L}$ (백색도), $\mathrm{a}$ (적색 도), $\mathrm{b}$ (황색도) 값을 측정하였다. 이 때 사용된 표준백판은
L: 92.38, a: $0.51, \mathrm{~b}: 3.21$ 이었다.

\section{우유식빵의 물성 측정}

블루베리 발효액종의 첨가량에 따른 우유식빵의 물성 측정은 Texture Analyzer(TA-XT2i, Stable Micro System Co., Surrey, UK)를 이용하여 TPA(texture profile analysis)로 측정하였고, $10 \mathrm{~mm}$ 의 두께로 슬라이스한 식빵을 두 장 포개어 측정하였다. 측정 조건은 test speed: $1.0 \mathrm{~mm} / \mathrm{s}$, distance: $50 \%$, probe: $\mathrm{p} / 45$ 이었고, 측정 후 얻어진 forcedistance curve로부터 식빵의 경도(hardness), 탄력성 (springiness), 응집성(cohesiveness), 점착성(gumminess), 씹 힘성(chewiness)의 평균값을 구하였다.

\section{통계처리}

본 연구의 실험결과는 IBM SPSS Statistics(19, IBM Corp., Armonk, NY, USA) 프로그램을 이용하여 분석하였 으며, 분석 방법에서 평균, 표준편차, 분산분석 그리고 Duncan의 다중범위 검정을 실시하였다.

\section{결과 및 고찰}

\section{발효시간에 따른 블루베리 발효액종의 $\mathrm{pH}$, 적정산도 및 가용성 고형분의 변화}

발효시간에 따른 블루베리 발효액종의 $\mathrm{pH}$, 적정산도 및 가용성 고형분의 변화를 측정한 결과는 Table 2 와 같다. 발효시간에 따른 블루베리 발효액종의 $\mathrm{pH}$ 는 제조 직후 6.34 이었고, 발효 48 시간째에는 4.29로 발효시간이 길어짐 에 따라 감소하는 경향을 보였고, 발효시간에 따라 유의한 차이가 있었다. 적정산도는 제조 직후 $0.21 \%$ 이었고, 발효 48 시간째에는 $1.34 \%$ 로 발효시간이 길어짐에 따라 증가하 는 경향을 보였고, 발효시간에 따라 유의한 차이가 있었다. 가용성 고형분은 제조 직후 $11.17{ }^{\circ} \mathrm{Brix}$ 이었고, 발효시간이 경과하면서 점차로 증가하여 발효 48 시간째에는 21.73 ${ }^{\circ} \mathrm{Brix}$ 이었으며, 발효 12 시간까지는 급격하게 증가하다가 이후로 완만하게 증가하는 경향을 보였다. 일반적으로 발 효가 진행됨에 따라 산도는 높아지는 반면 당의 함량은 감소하는 경향을 보이나 블루베리 발효액종의 경우 발효 시간이 길어짐에 따라 가용성 고형분이 계속 증가하는 경향 을 보였는데, 이는 발효액종의 제조에 사용된 건블루베리 가 설탕을 포함한 건조제품으로 인해 건블루베리 자체의 가용성 고형분이 $83{ }^{\circ} \mathrm{Brix}$ 로 높아 발효에 의한 당의 감소에 도 불구하고 당성분이 계속 액종에 녹아 나오기 때문으로 생각된다. $\operatorname{Kim}(28)$ 도 건포도의 당분이 물에 녹아들면서 발 효 1 일차에 건포도 발효액종의 가용성 고형분이 가장 높았 다고 하였고, 발효시간이 경과함에 따라 미생물이 건포도 의 당분을 이용하면서 산도가 증가하고 $\mathrm{pH}$ 는 감소하였다 고 보고하였다. 
Table 2. Changes in $\mathrm{pH}$, titratable acidity and soluble solid of blueberry starter by fermentation time

\begin{tabular}{cccc}
\hline $\begin{array}{c}\text { Fermentation time } \\
\text { (h) }\end{array}$ & $\mathrm{pH}$ & $\begin{array}{c}\text { Titratable acidity } \\
(\%)\end{array}$ & $\begin{array}{c}\text { Soluble solid } \\
\left({ }^{\circ} \text { Brix }\right)\end{array}$ \\
\hline 0 & $6.34 \pm 0.01^{1) 22)}$ & $0.21 \pm 0.01^{\mathrm{e}}$ & $11.17 \pm 0.06^{\mathrm{d}}$ \\
12 & $5.17 \pm 0.02^{\mathrm{b}}$ & $0.74 \pm 0.01^{\mathrm{d}}$ & $17.57 \pm 0.06^{\mathrm{c}}$ \\
24 & $4.88 \pm 0.02^{\mathrm{c}}$ & $1.02 \pm 0.01^{\mathrm{c}}$ & $18.33 \pm 0.12^{\mathrm{b}}$ \\
36 & $4.38 \pm 0.00^{\mathrm{d}}$ & $1.25 \pm 0.03^{\mathrm{b}}$ & $21.67 \pm 0.06^{\mathrm{a}}$ \\
48 & $4.29 \pm 0.00^{\mathrm{e}}$ & $1.34 \pm 0.02^{\mathrm{a}}$ & $21.73 \pm 0.06^{\mathrm{a}}$ \\
\hline
\end{tabular}

${ }^{1)}$ All values are mean $\pm \mathrm{SD}$.

${ }^{2}$ Mean \pm SD with different superscript within a column are significantly different $(\mathrm{p}<0.05)$ by Duncan's multiple range test.

\section{블루베리 발효액종의 첨가량에 따른 우유식빵 반죽의 발 효과정 중 부피 변화}

블루베리 발효액종의 첨가량에 따른 우유식빵 반죽의 발효과정 중 부피 변화를 측정한 결과는 Table 3 과 같다. 블루베리 발효액종의 첨가량에 따른 우유식빵 반죽의 부피 는 반죽 직후 모든 시료에서 $45.00 \mathrm{~mL}$ 이었으며, 1 차 발효 30 분부터 90 분까지 $40 \%$ 첨가구에서 $50.83-82.83 \mathrm{~mL}$ 로 가 장 높았고, $10 \%$ 첨가구에서 $50.08-75.75 \mathrm{~mL}$ 로 가장 낮게 나타났다. 2 차 발효 30 분부터 90 분까지의 부피에서도 $40 \%$ 첨가구가 72.75-122.33 mL로 가장 높았고, $10 \%$ 첨가구가 65.00-110.00 mL로 가장 낮았으며, 동일한 시료에서 발효시 간에 따른 유의한 차이가 있었고, 각각의 발효시간에서는 발효 직후에서 1 차 발효 60 분까지를 제외한 모든 발효시간 에서 시료 간에 유의한 차이를 보였다. 또한 $40 \%$ 첨가구에 비해 50\% 첨가구에서 발효력이 감소하는 경향을 보였는데, $\operatorname{Park}(29)$ 은 호밀가루에 물을 혼합하여 배양시킨 sourdough 의 함량이 빵의 제빵적성에 미치는 영향에 관한 연구에서 sourdough를 일정량 이상을 첨가하였을 때 유기산이 과도 하게 생성되어 글루텐의 구조를 약화시키고 가스포집력을 떨어뜨린다고 하였다.
블루베리 발효액종의 첨가량에 따른 우유식빵의 부피, 비 용적 및 굽기손실률

블루베리 발효액종의 첨가량에 따른 우유식빵의 부피, 비용적 및 굽기손실률을 측정한 결과는 Table 4 와 같다. 우유식빵의 부피는 $40 \%$ 및 $30 \%$ 첨가구에서 각각 $1,652.67$ $\mathrm{mL}$ 및 $1,642.00 \mathrm{~mL}$ 로 높았고, $50 \%$ 첨가구에서 $1,438.17$ $\mathrm{mL}$ 로 유의적으로 낮게 나타났다. 비용적은 부피와 마찬가 지로 $40 \%$ 첨가구에서 $3.31 \mathrm{~mL} / \mathrm{g}$ 로 가장 높았고, $50 \%$ 첨가 구에서 $2.85 \mathrm{~mL} / \mathrm{g}$ 로 가장 낮았으며, 시료간에 유의한 차이 가 있었다. 블루베리 발효액종의 첨가량에 따른 우유식빵 의 부피 및 비용적은 Table 3 의 반죽의 발효시간에 따른 부피 변화의 결과에서와 같이 $40 \%$ 첨가구에서 높은 값을 나타내었다. 굽기손실률은 $40 \%$ 및 $30 \%$ 첨가구에서 각각 $7.43 \%$ 및 $7.22 \%$ 로 높았고, $50 \%$ 첨가구에서 $6.57 \%$ 로 유의 적으로 낮게 나타났다. 반죽무게를 기준으로 하여 구운 후 식빵의 무게의 감소량을 백분율로 나타내는 굽기손실률은 빵이 부피가 클수록 굽는 과정에서의 수분손실이 많아 구운 후 식빵의 무게가 더 감소하는 결과를 보여 부피가 클수록 굽기손실률이 증가하는 경향을 보였다. 굽기 손실은 굽는 과정 중 반죽의 휘발성 물질이 열에 의해 휘발되면서 수분

Table 4. Volume, specific volume and baking loss of milk bread with blueberry starter

\begin{tabular}{cccc}
\hline $\begin{array}{c}\text { Blueberry starter } \\
(\%)\end{array}$ & $\begin{array}{c}\text { Volume } \\
(\mathrm{mL})\end{array}$ & $\begin{array}{c}\text { Specific volume } \\
(\mathrm{mL} / \mathrm{g})\end{array}$ & $\begin{array}{c}\text { Baking loss } \\
(\%)\end{array}$ \\
\hline 10 & $\left.1,460.27 \pm 3.41^{1) \mathrm{c} 2}\right)$ & $2.90 \pm 0.01^{\mathrm{d}}$ & $6.66 \pm 0.28^{\mathrm{b}}$ \\
20 & $1,609.50 \pm 5.07^{\mathrm{b}}$ & $3.21 \pm 0.02^{\mathrm{c}}$ & $7.01 \pm 0.38^{\mathrm{ab}}$ \\
30 & $1,642.00 \pm 8.19^{\mathrm{a}}$ & $3.28 \pm 0.01^{\mathrm{b}}$ & $7.22 \pm 0.12^{\mathrm{a}}$ \\
40 & $1,652.67 \pm 8.08^{\mathrm{a}}$ & $3.31 \pm 0.01^{\mathrm{a}}$ & $7.43 \pm 0.04^{\mathrm{a}}$ \\
50 & $1,438.17 \pm 10.40^{\mathrm{d}}$ & $2.85 \pm 0.01^{\mathrm{e}}$ & $6.57 \pm 0.33^{\mathrm{b}}$ \\
\hline
\end{tabular}

${ }^{1)}$ All values are mean \pm SD.

${ }^{2)}$ Mean $\pm \mathrm{SD}$ with different superscript within a column are significantly different $(\mathrm{p}<0.05)$ by Duncan's multiple range test.

Table 3. Changes in volume of milk bread dough with blueberry starter during fermentation

$(\mathrm{mL})$

\begin{tabular}{|c|c|c|c|c|c|c|}
\hline \multirow{2}{*}{\multicolumn{2}{|c|}{$\begin{array}{l}\text { Fermentation time } \\
(\min )\end{array}$}} & \multicolumn{5}{|c|}{ Blueberry starter (\%) } \\
\hline & & 10 & 20 & 30 & 40 & 50 \\
\hline \multirow{4}{*}{ Fermentation } & 0 & $45.00 \pm 0.00^{1) \mathrm{G} 2)}$ & $45.00 \pm 0.00^{\mathrm{G}}$ & $45.00 \pm 0.00^{\mathrm{G}}$ & $45.00 \pm 0.00^{\mathrm{G}}$ & $45.00 \pm 0.00^{\mathrm{G}}$ \\
\hline & 30 & $50.08 \pm 0.63^{\mathrm{F}}$ & $50.58 \pm 0.80^{\mathrm{F}}$ & $50.50 \pm 0.66^{\mathrm{F}}$ & $50.83 \pm 0.63^{\mathrm{F}}$ & $50.42 \pm 0.76^{\mathrm{F}}$ \\
\hline & 60 & $63.08 \pm 1.76^{\mathrm{E}}$ & $65.42 \pm 0.80^{\mathrm{E}}$ & $65.50 \pm 0.90^{\mathrm{E}}$ & $65.67 \pm 0.52^{\mathrm{E}}$ & $64.33 \pm 0.63^{\mathrm{E}}$ \\
\hline & 90 & $75.75 \pm 0.66^{\mathrm{dC}}$ & $77.67 \pm 0.52^{\mathrm{cC}}$ & $79.92 \pm 1.04^{\mathrm{bC}}$ & $82.83 \pm 0.88^{\mathrm{aC}}$ & $78.17 \pm 0.63^{\mathcal{C C}}$ \\
\hline \multirow{3}{*}{$\begin{array}{l}2^{\text {nd }} \\
\text { Fermentation }\end{array}$} & 30 & $65.00 \pm 0.25^{\mathrm{cD}}$ & $66.83 \pm 0.63^{\mathrm{bD}}$ & $67.17 \pm 0.38^{\mathrm{bD}}$ & $72.75 \pm 0.90^{\mathrm{aD}}$ & $66.92 \pm 0.80^{\mathrm{bD}}$ \\
\hline & 60 & $87.17 \pm 0.80^{\mathrm{AB}}$ & $88.17 \pm 0.63^{\mathrm{dB}}$ & $90.75 \pm 0.50^{\mathrm{cB}}$ & $96.58 \pm 0.80^{\mathrm{aB}}$ & $94.42 \pm 0.63^{\mathrm{bB}}$ \\
\hline & 90 & $110.00 \pm 0.25^{\mathrm{eA}}$ & $112.08 \pm 0.72^{\mathrm{dA}}$ & $115.42 \pm 0.72^{\mathrm{cA}}$ & $122.33 \pm 0.95^{\mathrm{aA}}$ & $117.08 \pm 0.72^{\mathrm{bA}}$ \\
\hline
\end{tabular}

${ }^{1)}$ All values are mean $\pm S D$.

${ }^{2)}$ Mean $\pm \mathrm{SD}$ with different superscript within a column are significantly different $(\mathrm{p}<0.05)$ by Duncan's multiple range test. ${ }^{\text {at }}$ Means Duncan's multiple range test for different addition (row). A-Geans Duncan's multiple range test for fermentation time (column). 
이 증발하여 발생되는데 부피가 큰 반죽일수록 열과 접촉하 는 면적이 넓어 굽기손실률이 증가하는 것으로 알려져 있다 $(18,30)$.

블루베리 발효액종의 첨가량에 따른 우유식빵의 수분함량 우유식빵의 수분함량을 측정한 결과는 Table 5 와 같다. 블루베리 발효액종의 첨가량에 따른 우유식빵의 수분함량 은 50\% 및 $10 \%$ 첨가구에서 각각 $39.45 \%$ 및 $39.32 \%$ 로 높았 고, $40 \%$ 및 $30 \%$ 첨가구에서 각각 $38.86 \%$ 및 $38.84 \%$ 로 유의적으로 낮게 나타났다. 이러한 결과는 Table 4의 우유 식빵의 부피, 비용적 및 굽기손실률 측정결과와 연관된 결 과로 부피와 비용적이 높을수록 굽는 과정 중 수분의 손실 이 많아 우유식빵의 최종 수분함량에 영향을 미쳤다고 사료 된다. Yeom 등(31)도 보릿잎차의 대체량이 많아질수록 빵 반죽의 부피가 감소하고, 오븐열과 반응하는 표면적이 적 어 굽는 과정 중 수분증발이 낮아져 빵의 수분함량은 높았 다고 하였고, 이 외에도 첨가재료에 함유된 식이섬유와 당 류의 수분보유력이 최종제품의 수분함량에 영향을 준다는 연구들이 보고되었다(32-34).

Table 5. Moisture content of milk bread with blueberry starter

\begin{tabular}{cc}
\hline Blueberry starter(\%) & Moisture content(\%) \\
\hline 10 & $\left.39.32 \pm 0.09^{1 \mathrm{a} 2} 2\right)$ \\
20 & $39.08 \pm 0.47^{\mathrm{ab}}$ \\
30 & $38.84 \pm 0.12^{\mathrm{b}}$ \\
40 & $38.86 \pm 0.10^{\mathrm{b}}$ \\
50 & $39.45 \pm 0.03^{\mathrm{a}}$ \\
\hline
\end{tabular}

\footnotetext{
${ }^{1)}$ All values are mean $\pm \mathrm{SD}$

${ }^{2} \mathrm{Mean} \pm \mathrm{SD}$ with different superscript within a column are significantly different $(\mathrm{p}<0.05)$ by Duncan's multiple range test.
}

블루베리 발효액종의 첨가량에 따른 우유식빵의 단면구조 우유식빵의 단면을 촬영한 결과는 Fig. 1과 같다. 우유식 빵의 단면구조를 관찰한 결과, $30 \%$ 및 $40 \%$ 첨가구의 기공 이 크게 관찰되어 부피와 비용적이 클수록 기공의 크기가 크게 나타나는 경향을 보였다. 식빵의 부피는 최종제품의 중요한 품질평가 요인으로 부피의 감소는 내부기공을 조밀 하게 한다고 하였고(35,36), Byun 등(37)도 오미자청으로 발효시킨 쌀가루 sourdough의 첨가량이 높을 때 빵의 외형 과 기공이 작아지는 경향을 보였다고 하였다.
블루베리 발효액종의 첨가량에 따른 우유식빵의 색도

블루베리 발효액종 첨가량에 따른 우유식빵의 crumb 부 분과 crust 부분의 색도를 측정한 결과는 Table 6과 같다. Crumb 부분의 $\mathrm{L}$ 값은 $10 \%$ 첨가구에서 67.51 로 유의적으로 높았고, 발효액종의 첨가량이 증가할수록 감소하는 경향을 보였다. a 값과 b 값은 $50 \%$ 첨가구에서 각각 1.22 및 12.52 로 가장 높았고, 시료간에 유의한 차이가 있었으며, 발효액종 의 첨가량이 많을수록 대체로 높은 경향을 보였다. Crust 부분의 $\mathrm{L}, \mathrm{a}$ 및 b 값은 모두 $50 \%$ 첨가구에서 가장 높았고, $10 \%$ 첨가구에서 가장 낮았으며, 블루베리 액종의 첨가량이 많아질수록 증가하는 경향을 보였다. Im과 Lee(38)는 흑미 가루의 첨가량이 증가할수록 쌀식빵 내부의 $\mathrm{L}$ 값은 현저히 감소하는 반면 적색도인 a 값은 증가하였다고 하였고, Bing 등(11)도 머루 sourdough의 대체량이 증가할수록 crumb 부 분의 적색도가 유의적으로 높아졌다고 하여 본 연구와 같은 결과를 보고하였다.

\section{블루베리 발효액종의 첨가량에 따른 우유식빵의 물성}

블루베리 발효액종 첨가량에 따른 우유식빵의 물성을 측정한 결과는 Table 7과 같다. 우유식빵의 경도는 $50 \%$ 첨가구에서 $0.85 \mathrm{~kg}$ 으로 가장 높았고, $40 \%$ 첨가구에서 0.58 $\mathrm{kg}$ 으로 가장 낮았으며, 시료 간에 유의적인 차이가 있었다. 압착에 대한 복원력을 나타내는 탄력성은 0.82-0.88이었고, 응집성은 $0.52-0.54$ 이었으며, 탄력성과 응집성은 시료간에 유의한 차이를 보이지 않았다. 점착성 및 씹힘성은 $40 \%$ 첨가구에서 유의적으로 낮게 나타났다. 식빵의 경도는 부 피와 함께 식빵의 품질을 결정하는 중요한 인자로, 부피, 기공의 발달정도, 수분함량 등과 밀접한 관련이 있으며, 기공이 잘 발달하면 부피는 커지고 경도는 낮아져 부드러운 식빵이 된다고 하였다(1). 블루베리 발효액종의 첨가량에 따른 우유식빵의 경도는 $40 \%$ 첨가 시까지 감소하였으나 $50 \%$ 첨가구에서 가장 높게 나타났는데, Table 4의 우유식빵 부피와 연관된 결과로 $50 \%$ 첨가구에서는 식빵의 기공이 잘 발달하지 못하여 부피가 작아지면서 경도가 높아진 것으 로 사료되며 Table 5의 수분함량에는 크게 영향을 받지 않는 것으로 나타났다. An과 Lee(39)와 Wang 등(40)도 크랜 베리와 흑마늘 추출액을 첨가한 식빵의 품질특성에 관한 연구에서 식빵의 부피와 경도의 연관성을 보고하였다. 물 성의 결과를 종합해 보면 $40 \%$ 첨가구에서 경도가 가장 낮음을 알 수 있으며, $50 \%$ 첨가구에서는 식빵의 부피감소

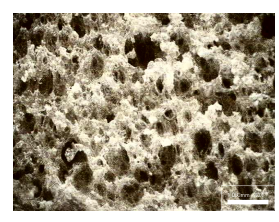

$10 \%$

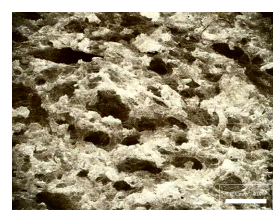

$20 \%$

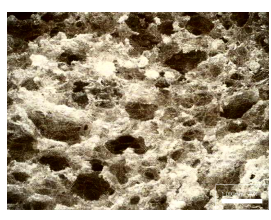

$30 \%$

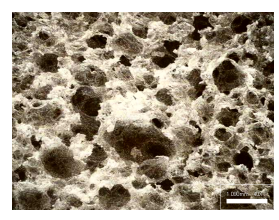

$40 \%$

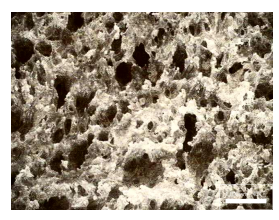

$50 \%$

Fig. 1. Cross section structure of milk bread with blueberry starter. 
Table 6. Color value of milk bread with blueberry starter

\begin{tabular}{|c|c|c|c|c|c|c|}
\hline \multirow{2}{*}{ Blueberry starter (\%) } & \multicolumn{3}{|c|}{ Crumb } & \multicolumn{3}{|c|}{ Crust } \\
\hline & $\mathrm{L}$ & $\mathrm{a}$ & $\mathrm{b}$ & $\mathrm{L}$ & $\mathrm{a}$ & $\mathrm{b}$ \\
\hline 10 & $67.51 \pm 0.31^{\left.1)^{2} 2\right)}$ & $-0.41 \pm 1.05^{\mathrm{ab}}$ & $10.72 \pm 0.51^{\mathrm{c}}$ & $32.45 \pm 0.18^{\mathrm{e}}$ & $14.87 \pm 0.27^{b}$ & $17.15 \pm 0.23^{\mathrm{d}}$ \\
\hline 20 & $65.86 \pm 0.71^{\mathrm{b}}$ & $-1.79 \pm 0.51^{b}$ & $11.15 \pm 0.72^{\mathrm{bc}}$ & $32.90 \pm 0.44^{\mathrm{d}}$ & $15.14 \pm 0.72^{b}$ & $18.01 \pm 0.57^{\mathrm{c}}$ \\
\hline 30 & $64.95 \pm 0.38^{c}$ & $0.02 \pm 0.78^{\mathrm{ab}}$ & $11.35 \pm 0.61^{\mathrm{bc}}$ & $33.49 \pm 0.28^{c}$ & $15.21 \pm 0.57^{b}$ & $17.89 \pm 0.55^{\mathrm{c}}$ \\
\hline 40 & $64.21 \pm 0.56^{\mathrm{d}}$ & $0.96 \pm 3.13^{\mathrm{a}}$ & $11.91 \pm 0.53^{\mathrm{ab}}$ & $36.27 \pm 0.21^{\mathrm{b}}$ & $16.51 \pm 0.29^{\mathrm{a}}$ & $21.40 \pm 0.36^{b}$ \\
\hline 50 & $60.14 \pm 0.52^{\mathrm{e}}$ & $1.22 \pm 0.93^{\mathrm{a}}$ & $12.52 \pm 0.86^{\mathrm{a}}$ & $36.74 \pm 0.22^{\mathrm{a}}$ & $16.84 \pm 0.41^{\mathrm{a}}$ & $21.99 \pm 0.54^{\mathrm{a}}$ \\
\hline
\end{tabular}

${ }^{11}$ All values are mean $\pm \mathrm{SD}$.

${ }^{2)}$ Mean \pm SD with different superscript within a column are significantly different $(\mathrm{p}<0.05)$ by Duncan's multiple range test.

Table 7. Texture of milk bread with blueberry starter

\begin{tabular}{cccccc}
\hline Blueberry starter $(\%)$ & Hardness $(\mathrm{kg})$ & Springiness & Cohesiveness & Gumminess & Chewiness \\
\hline 10 & $0.80 \pm 0.05^{1 \mathrm{ab} 2)}$ & $0.83 \pm 0.05$ & $0.54 \pm 0.02$ & $0.43 \pm 0.03^{\mathrm{a}}$ & $0.36 \pm 0.04^{\mathrm{a}}$ \\
20 & $0.77 \pm 0.07^{\mathrm{ab}}$ & $0.85 \pm 0.06$ & $0.53 \pm 0.02$ & $0.41 \pm 0.03^{\mathrm{a}}$ & $0.35 \pm 0.03^{\mathrm{a}}$ \\
30 & $0.74 \pm 0.06^{\mathrm{b}}$ & $0.88 \pm 0.04$ & $0.54 \pm 0.01$ & $0.40 \pm 0.04^{\mathrm{a}}$ & $0.35 \pm 0.03^{\mathrm{a}}$ \\
40 & $0.58 \pm 0.05^{\mathrm{c}}$ & $0.87 \pm 0.05$ & $0.54 \pm 0.01$ & $0.31 \pm 0.02^{\mathrm{b}}$ & $0.27 \pm 0.02^{\mathrm{b}}$ \\
50 & $0.85 \pm 0.08^{\mathrm{a}}$ & $0.82 \pm 0.04$ & $0.52 \pm 0.01$ & $0.44 \pm 0.04^{\mathrm{a}}$ & $0.36 \pm 0.04^{\mathrm{a}}$ \\
\hline
\end{tabular}

\footnotetext{
${ }^{1)}$ All values are mean $\pm \mathrm{SD}$

${ }^{2)}$ Mean \pm SD with different superscript within a column are significantly different $(\mathrm{p}<0.05)$ by Duncan's multiple range test.
}

로 인해 경도가 증가하는 결과를 보였다. 실험의 결과로 볼 때, 블루베리 발효액종을 제빵에 활용할 경우, $40 \%$ 첨가 가 식빵의 경도를 낮추어 더 부드러운 빵을 제조하는데 도움을 줄 것으로 생각된다.

\section{요 약}

본 연구에서는 블루베리를 이용하여 액종을 제조하고, 이를 첨가한 우유식빵의 품질특성을 측정하였다. 발효시간 이 경과함에 따라 블루베리 발효액종의 $\mathrm{pH}$ 는 감소하였고, 적정산도 및 가용성 고형분은 증가하였다. 블루베리 발효 액종 첨가량에 따른 우유식빵 반죽의 부피는 $40 \%$ 첨가구에 서 가장 높았다. $30 \%$ 및 $40 \%$ 첨가구에서 우유식빵의 부피 와 굽기손실률은 가장 높았고, 수분함량은 가장 낮았다. 우유식빵의 crumb 부분의 색도를 측정한 결과, 블루베리 발효액종의 첨가량이 많아질수록 $\mathrm{L}$ 값은 감소하고 $\mathrm{a}$ 값과 $\mathrm{b}$ 값은 증가하는 경향을 보였다. 물성 측정 결과에서, 우유 식빵의 경도, 점착성 및 씹힘성은 $40 \%$ 첨가구에서 가장 낮았다. 따라서, 우유 식빵의 제조에 있어서 블루베리 발효 액종을 30-40\% 첨가하였을 때 품질이 우수한 식빵을 제조 할 수 있을 것으로 생각된다.

\section{References}

1. Joen KS, Lee NH, Park SI (2015) Quality characteristics of white pan bread with chinese artichoke (Stachys sieboldii MIQ) powder. Korean J Culinary Res, 21, 1-15

2. Hwang SW, Park MH, Shim HK, Bae MJ (1994) Studies on the composition of lipid, amino acid and dietary fiber from functional food source-Platycodi radix, perilla seed, evening primrose seed and aloe vera-. J Korean Soc Food Nutr, 23, 647-653

3. Kim HK (2004) Current status and prospect of nutraceuticals. Food Industry and Nutrition, 9, 1-14

4. Lee HY, Kim SM, Kim JY, Youn SK, Choi JS, Park SM, Ahn DH (2002) Effect of addition of chitosan on improvement for shelf life of bread. J Korean Soc Food Sci Nutr, 31, 445-450

5. Jung IC (2006) Rheological properties and sensory characteristics of white bread with added mugwort powder. J East Asian Soc Diet Life, 16, 332-343

6. Kim KH, Song MY, Yook HS (2007) Quality characteristics of bread made with Chungkulgang powder. J East Asian Soc Diet Life, 17, 853-859

7. Jeong $\mathrm{CH}$, Cho HJ, Shim KH (2006) Quality characteristics of white bread added with chlorella powder. Korean J Food Preserv, 13, 465-471 
8. Lee JH, Kang SH, Kim MR (2011) Changes in the quality characteristics and antioxidant activities of spirulina added bread during storage. Korean J Food Preserv, 18, 111-118

9. Choi SH, Lee SJ (2014) Quality characteristics of Korean wheat bread prepared with substitutions of naturally fermented rice starters. Korean J Culinary Res, 20, 100-119

10. Choi DM, Lee DS, Chung SK (2007) Effects of fermentation pine needle extract on the quality of plain bread. Korean J Food Preserv, 14, 154-159

11. Bing DJ, Kim WT, Chun SS (2014) Development of white bread using fermented wild grape sourdough. J Korean Soc Food Sci Nutr, 43, 1896-1905

12. Kim MY, Chun SS (2008) Quality characteristics of rye mixed bread prepared with substitutions of naturally fermented raisin extract and sourdough. J East Asian Soc Diet Life, 18, 89-94

13. Ko SJ (2013) Naturally fermented bread. IFAD publisher. Seoul, Korea, p 15

14. An CH (2013) Natural starter bread. IFAD publisher. Seoul, Korea, p 8

15. An CH (2013) Natural starter Bread. IFAD publisher. Seoul, Korea, p 9

16. Kim YE, Paik HD, Kim SY, Lee JH, Lee SK (2011) Effects of liquid broth cultured with red koji on the rheological properties of white pan bread dough. Korean J Food Sci Technol, 43, 235-239

17. Jung KT, Park BG, Lee MH (2017) Quality characteristics of sourdough bread using fermented fig. Culinary Sci Hospitality Res, 23, 56-65

18. Lee JH, Kwak EJ, Kim JS, Lee KS, Lee YS (2007) A study on quality characteristics of sourdough breads with addition of red yeast rice. J Korean Soc Food Sci Nutr, 36, 785-793

19. Cheon MG, Kwon JH, Jeong GS, Kim MK, Chong BM, Kang ND, Shon GM, Park CS (2010) Cultural and pathogenic characteristics causing anthracnose in blueberry. Korean J Hortic Sci Thechnol, 28, 41-45

20. Jeon MH, Lee WJ (2011) Characteristics of blueberry added Makgeolli. J Korean Soc Food Sci Nutr, 40, 444-449

21. Han JM, Chung HJ (2013) Quality characteristics of Yanggaeng added with blueberry powder. Korean J Food Preserv, 20, 265-271

22. Jeong CH, Choi SG, Heo HJ (2008) Analysis of nutritional compositions and antioxidative activities of
Korean commercial blueberry and raspberry. J Korean Soc Food Sci Nutr, 37, 1375-1381

23. Lee SN, Kang GJ (2010) The Effect of blueberry extract on gene expressions related to apoptosis in human breast cancer MCF7 cells. J East Asian Soc Diet Life, 20, 30-36

24. Jo YN, Jin DE, Jeong JH, Kim HJ, Choi SG, Heo HJ (2014) Nutritional composition and antioxidantantiacetylcholinesterase activities of blueberry (Vaccinium virgatum). J Agric Life Sci, 48, 241-251

25. Cho WJ, Song BS, Lee JY, Kim JK, Kim JH, Yoon YH, Choi JI, Kim GS, Lee JW (2010) Composition analysis of various blueberries produced in Korea and manufacture of blueberry jam by response surface methodology. J Korean Soc Food Sci Nutr, 39, 319-323

26. Campbell AM, Penfield MP, Griswold RM (1979) The experimental study of food. Houghton Mifflin Co, Boston, MA, USA, p 459

27. AOAC (1984) Official methods of analysis. $14^{\text {th }} \mathrm{ed}$, Association of Official Analytical Chemists, Washington DC, USA, p 31-47

28. Kim SY (2012) A study on the quality characteristics of pan bread added with GABA rice bran sourdough. MS Thesis, Yeungnam University, Korea, p 13

29. Park SJ (2012) Influence of sourdough content on the bread making properties of rye meal-wheat flour composite bread. MS Thesis, Korea University, Korea, p 18-19

30. Bae JH, Lee JH, Kwon KI, Im MH, Park GS, Lee JG, Choi HJ, Jeong SY (2005) Quality characteristics of the white bread prepared by addition of jujube extract. Korean J Food Sci Technol, 37, 603-610

31. Yeom KH, Kim MY, Chun SS (2010) Quality characteristics of white bread with barley leaves tea powder. Korean J Food Cookery Sci, 26, 398-405

32. Moon HK, Han JH, Kim JH, Kim JK, Kang WW, Kim GY (2004) Quality characteristics of the breads added with freeze dried old pumpkin powders. Korean J Soc Food Cookery Sci, 20, 126-132

33. Shin HK, Lee JH, Lee SK (2017) Characteristics of white pan bread with roasted rice bran. Korean J Food Sci Technol, 49, 401-407

34. Kim YJ, Lee JH, Chung KC, Lee SK (2014) Effects of trehalose on quality characteristics of white pan bread. J Korean Soc Food Sci Nutr, 43, 712-719

35. Chung YK, Jang DH (2015) Effects of fermented liquid dough on bread quality. Korean J Community Living Sci, 26, $127-133$ 
36. Campana LE, Sempe ME, Filgueira RR (1993) Physical, chemical, and baking properties of wheat dried with microwave energy. Cereal Chem, 70, 760-762

37. Byun JB, Chang JH, Jeoung GY, Lee JS (2015) Effect of rice flour sourdough fermented with Omija (Schizandra chinensis) extract on quality characteristics of bread. Korean J Food Sci Technol, 47, 704-710

38. Im JS, Lee YT (2010) Quality characteristics of rice bread substituted with black rice flour. J East Asian Soc Diet Life, 20, 903-908

39. An HR, Lee KS (2010) Quality characteristics of pan bread by the addition of cranberry powder. J East Asian Dietary Life, 20, 697-705

40. Wang SJ, Lee JH, Lee SK (2013) Effect of black garlic extracts on quality characteristics of white pan bread. J Korean Soc Food Sci Nutr, 42, 1283-1289 